\title{
ORTHOPTEROID INSECTS FROM THE MARITIME PROVINCE OF SIBERIA
}

\author{
By A. N. Caudell
}

Of the Bureau of Entomology, United States Department of Agriculture

In July and August, 1923, Prof. T. D. A. Cockerell and his wife collected insects at and about Vladivostok in Siberia and at various localities for a distance of some four hundred miles northeast of that place. An interesting account of this excursion appears on pages 415-433 of the Scientific Monthly (vol. 29, 1924). The following report is on the Orthopteroid insects taken on the above trip, all of which are deposited in the United States National Museum.

\section{Order DERMAPTERA}

\section{Family FORFICULIDAE}

\section{Subfamily ForficulinaE}

\section{ANECHURA ATHYMIA Rehn}

A pterygida athymia Renn, Proc. U.S. Nat. Mus., vol. 27, 1904, p. 540.

One adult male from Kongaus in August and one nymph from Okeanskaya, also in August.

This male agrees structurally with one from Soochow, China, determined as this species, but the color is noticeably darker. The nymph here recorded has the abdomen missing.

\section{FORFICULA TOMIS Kolenati}

Chelidura tomis Kolenati, Melet. Ent., vol. 5, 1846, p. 74, pl. 17, fig. $6 a$.

One male, Kongaus in August.

\section{FORFICULA VICARIAE Semenov}

Forficula vicariae Semenov, Rev. Russ. d'Ent., vol. 2, 1902, pp. 99, 100, fig. 1.

Two males, Kongaus in August. Also a female nymph of a Forficula which may perhaps belong to this species was taken at Low Lighthouse, a hundred miles or so north of Kongaus, on July 13.

No. 2679.-PRoceEdings U. S. NATIIONAL'MUSEum, Vol. 7 I, ART. 7 


\title{
Order ORTHOPTERA
}

\author{
Family BLATTIDAE \\ Subfamily Pseudomopinae
}

BLATTELLA GERMANICA Linnaeus

Blalta germanica Linnaeus, Syst. Nat., ed. 12, vol. 1, 1767, p. 668.

One female, Kongaus in August. Professor Cockerell also brought home a male from Japan. This latter specimen, together with six others from Japan now in the National Museum collection, exhibits decided variation in size and in pronotal coloration, the median stripe of the pronotal disk being continuous to the posterior margin in some specimens while in others it falls noticeably short of that margin, and in some specimens, especially noticeable in one female examined, this stripe is narrower than common, being about as in Indian specimens determined by Mr. Hebard as Blattella cognata Brunner.

\section{Family ACRIDIDAE \\ Subfamily TetriginaE \\ ACRYDIUM SIBERICUM Bolivar}

Tettix sibericus Bolivar, Ann. Soe. Ent. Belg,, vol. 31, 1887, pp. 187, 258, 265.

Three females, one from Amagu on the Kudia River in July and two from Okeanskaya in August.

\section{ACRYDIUM FULIGINOSUM ? Zetterstedt}

Acridium fuliginosum Zetterstedt, Fauna Ins. Lapp., vol, 1, 1828, p. 452.

One female nymph from Amagu on the Kudia River perhaps belongs here. The fastigum of the vertex extends decidedly further anterior of the eyes than in the specimens determined above as sibericum.

\section{Subfamily ACRIDINAE}

\section{PODISMOPSIS USSURIENSIS Ikonnikov}

Podismopsis ussuriensis Ikonnıkov, Ann. Mus. Zool. St. Petersb., vol. 16, 1911, p. 246.

Two males in July, one at Preobrageniya Bay and one at Barhatnaye near Kongaus, and one female at Kongaus in August.

GOMPHOCERUS SIBERICUS, var. KUDIA, new variety

Male.-Structurally very much like typical sibericus, with the anterior tibiae greatly swollen, as characteristic of that form. The size is, however, so much greater that a varietal name seems almost a necessity. The thorax in the two specimens examined is almost black, much darker than usual in typical sibericus, but this is perhaps subject to variation. 
Measurements.-Length, pronotum, $5.5 \mathrm{~mm}$; antennae, about 10 mim.; posterior femora, $12 \mathrm{~mm}$; t tegmina, $19 \mathrm{~mm}$.

Type locality.-Amagu on the Kudia River, Siberia.

Described from two males, type and paratype, collected by T. D. A. Cockerell in July, 1923.

Type.-Cat. No. 29212, U.S.N.M.

A female nymph bearing the same data as the type probably belongs here.

\section{MEGAULACOBOTHRUS KONGAUSENSIS, new species}

Male.-Superficially very like Megaulacobothrus fuscipennis Caudell, but is smaller, the tip of the abdomen not red and the tegminal vena-

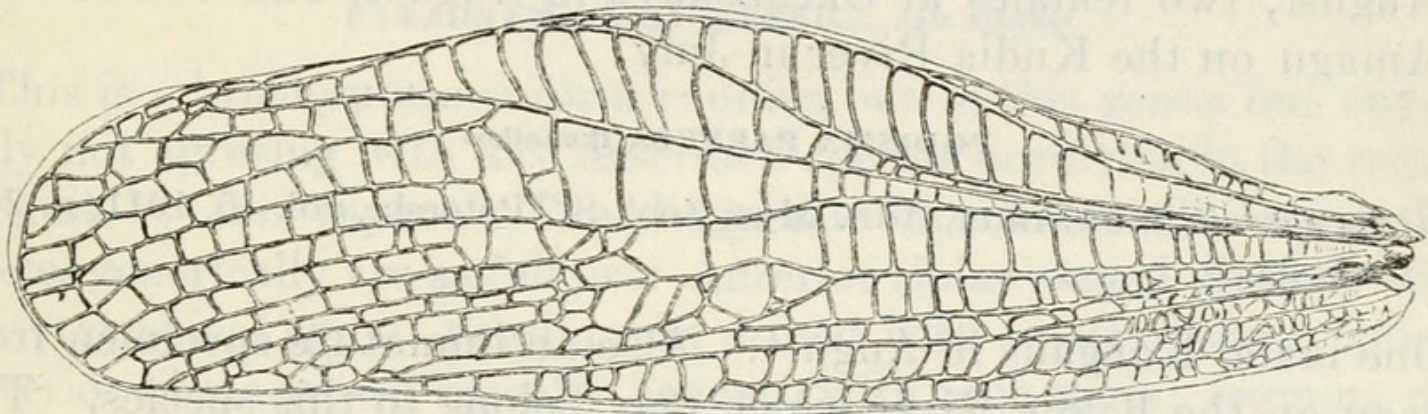

Fig. 1.-TEgMen of M. KONGAUSENSIS, NEW SPECIES

tion very different. The anterior radial vein of the tegmen diverges suddenly from the posterior one a little basad of the middle and extends to the anterior edge of the tegmen; figure 1 shows the tegmen of this new species while figure 2 shows that of fuscipennis. The wings are similar in the two species, being uniformly and rather

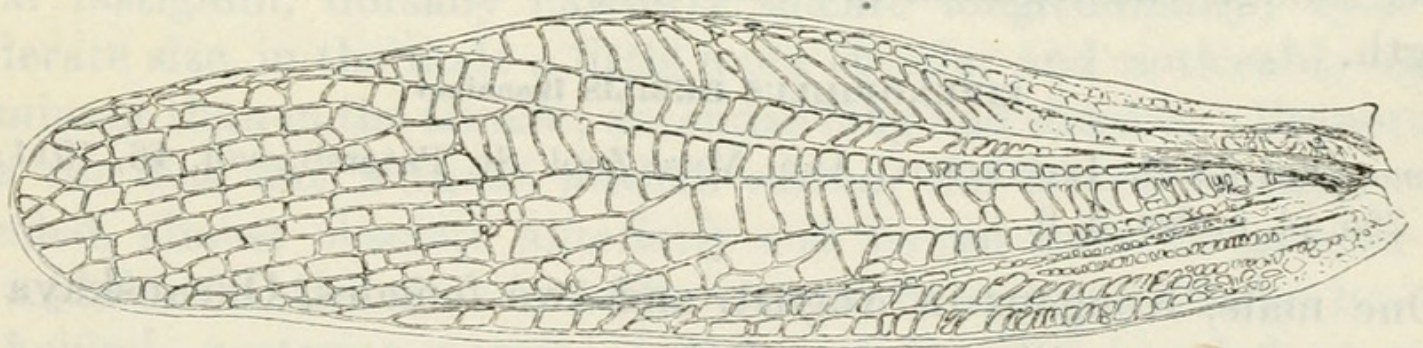

Fig. 2.-TEgMen of M. FUSCipennis CaUdell

deeply fuliginous, a feature suggested by the name fuscipennis but unfortunately omitted from the original description of that species.

The posterior tibiae are yellowish in the new species now under discussion, instead of red as in fuscipennis, and the posterior femora are yellow with the geniculations black.

Measurements.-Length, pronotum, $4 \mathrm{~mm}$.; antennae, about $12 \mathrm{~mm}$.; tegmina, $19 \mathrm{~mm}$.; posterior femora, $11 \mathrm{~mm}$.; width, tegmina at widest point, $5.25 \mathrm{~mm}$.

Type locality.-Kongaus, Siberia. 
Described from three adult males, type and paratypes, collected by T. D. A. Cockerell in August.

Type.-Cat. No. 29213, U.S.N.M.

\section{STAURODERUS BIGUTTLLUS Linnaeus}

Gryllus locusta biguttulus Linnaeds, Syst. Nat., ed. 10, vol. 1, 1758, p. 433.

Three males, Kongausin August; one female, Okeanskaya in August.

\section{Subfamily CYPTACANTHACRINAE \\ PRUMNA PRIMNOA Fischer von Waldheim}

Podisma primnoa Fischer von Waldheim, Orth. Ross., 1846, p. 248.

Four males and five females, the males and one female at Kongaus in August, two females at Okeanskaya in August, and two females at Amagu on the Kudia River in July.

PODISMA PARVULA Tkonnikov

Podisma parvula Ikonnikov, Ann. Mus. Zool. St. Petersb., vol. 16, 1911, p. 260' pl. 5 , fig. 3.

One male, Kongaus in August. Also an immature specimen from Amagu on the Kudia River which may belong to this species. The adult male agrees with specimens of that sex in the National Museum determined by Ikonnikov except that the pronotal disk is not notched posteriorly.

\section{PODISMA FRIGIDA Boehman}

Gryllus firigidus Boенмan, Oefv. Vet.-Akad. Förh., 1846, p. 80.

One female from Amagu on the Kudia River in July is referred here, though the tegmina ąre unusually long, measuring $16 \mathrm{~mm}$. in length.

\section{EIRENOPHILUS DEBILIS Ikonnikov}

Eirenophilus debilis Iкоммгкоv, Ann. Mus. Zool. St. Petersb., vol. 16, 1911, p. 265 , pl. 5, figs. 5 , 6 .

One male, Kongaus in August, and two females, Okeanskaya in August.

\section{Family TETTIGONIIDAE}

\section{Subfamily DECTICINAE}

\section{GAMPSOCLEIS SEDAKOVII Fischer von Waldheim}

Decticus sedakovii Fischer von Waldheim, Orth. Ross., 1846, p. 161, pl. 28, figs. 2, 3 .

One male, Amagu on the Kudia River in July.

Gampsocleis tamerlana Burr, G. spinulosa Krauss, G. sowinskyi Adelung, G. kraussi Adelung, and G. kraussi, var. baicalensis Adelung are listed as synonyms of this species. Burr, in his original description 
of tamerlana, states that the cerci of the male are armed mesially with a large obtuse inner spine, but Uvarov, who studied the type of that species, relegates it to the synonymy under sedakovii and figures the cerci of the latter as with the inner tooth decidedly basad of the middle, which agrees with the specimen here recorded, the cercus of which is intermediate between those figured by $\mathrm{Uvarov}^{1}$ for G. kraussi and G. kraussi, var. baicalensis. The range of variation in the cercal shape as brought out by Uvarov in the above-noted figures would seem to indicate that this character is scarcely more dependable for specific differentiation than those of femoral armature, shape of subgenital plate, and others which that writer decries as unreliable or as of no importance whatsoever.

\section{PARADRYMADUSA SIBERICA, new species}

This is a brachypterous form running out to this genus but apparently not agreeing with any described species occurring in the region covered by this report. The diagnostic characters allocating this species generically are as follows: Anterior tibiae armed dorsally with an outer apical spine; prosternum armed with a pair of short spines ; posterior tibiae armed apically beneath with four spurs; tegmina not exceeding the tip of the abdomen; pronotum moderately produced posteriorly, without median carina; ovipositor curved gently downwards; plantula of posterior tarsus quadrate, less than half as long as the basal segment of the tarsus; anal dorsal segment of the male posteriorly emarginate and the cerci short.

Male and female.- Head equal in width with the pronotum; rertex as broad as the basal segment of the antenna, beneath meeting the facial fastigium, dorsally narrowly sulcate longitudinally; eyes of moderate size, in the male a little more circular and noticeably more prominent than in the female; antennae long and slender. Pronotum with the disk flat, without median carina, the lateral carinae very rounded, almost obsolete anteriorly and bowed inwards anterior of the middle, the disk thus broarder anteriorly and posteriorly, broadest behind; posterior margin of disk very broadly rounded, or subtruncate, the anterior margin subtruncate or very slightly concave; lateral lobes subvertical and well developed, being about as deep as long, the margins slanting, the anterior ones very slightly so and the posterior ones very much so; humeral sinus barely indicated; prosternal spines short, varying from scarcely longer than the basal width to decidedly elongate. Abdomen with the last dorsal segment of the male posteriorly mesially roundly notched, in the female bent downwards and concave; subgenital plate of the male as long as 
broad, beneath basally sulcate longitudinally and laterally bicarinate anteriorly, apically furnished with a pair of obscurely segmented styles about five times as long as broad, the posterior margin of the plate between the styles nearly straight; subgenital plate of the female transverse, posteriorly broadly triangularly notched; cerci of both sexes short, about twice as long as basally thick, in the female cylindrical and simple, tapering to a rather sharp and gently incurved point, in the male more abruptly tapering apically to a sharp and abruptly incurved tooth and armed with a small triangular point near the base of the apical tooth on the dorsal flange formed by the flattened inner surface of the cercus; ovipositor longer than the body and curving gently downwards, the tip rather abruptly tapering, more on the dorsal margin, to a sharp point.

Legs rather slender; plantula of posterior tarsi no longer than broad, less than one-half as long as the basal tarsal segment; anterior tibiae with three dorsal spines on the outer margin, one apical, one mesial and one at the apex of the conchate foramen, and with a single apical spine on the inner margin, beneath armed with six long spines on each margin; middle tibiae with four spines on each dorsal margin and six or seven on each ventral margin; posterior tibire armed above and below on both margins, above armed nearly to the base, the apical pair of spines much the longest, and beneath armed for a lesser distance with smaller spines, the apical ventral calcars four in number, the inner pair about one-half as long as the outer pair; anterior and intermediate femora unarmed above, beneath unarmed or armed with from one to three small teeth on the caudal margin; posterior femora long, greatly swollen in the basal third, beyond more slender and armed beneath on each margin with several short, sharp black teeth.

Tegmina short and broad in both sexes, not or but little longer than the pronotum, apically broadly rounded, in the female but little overlaping above, in the male strongly so; stridulating tympanum of the male well developed; wings narrow, slightly more than one-half as long as the tegmina.

Measurements.-Length, pronotum, male $7 \mathrm{~mm}$., female $7.25 \mathrm{~mm}$.; tegmina, male $11 \mathrm{~mm}$., female $8 \mathrm{~mm}$.; posterior femora, male $25 \mathrm{~mm}$., female $26 \mathrm{~mm}$.; ovipositor, $28 \mathrm{~mm}$; width, pronotum posteriorly, male $4.5 \mathrm{~mm}$., female $5 \mathrm{~mm}$.; posterior femora at widest point, male $4 \mathrm{~mm}$., female $4.5 \mathrm{~mm}$.

Type locality.-Kongaus, Siberia.

Described from one male and three females, all adults, taken by T. D. A. Cockerell in August, 1923.

Type, male; allotype, female; paratypes A and B, females.

Type.-Cat. No. 29214, U.S.N.M. 


\section{Subfamily CoNOCEPHALINAE}

\section{CONOCEPHALUS LONGIPENNIS Haan}

Locusta (Xiphidium) longipennis HAAN, Temminck Verhandel., Orth., 1842, p. 189.

Two adult females, Kongaus, and one adult female and an immature male, Okeanskaya, all in August.

\section{Subfamily Phaneropterinae}

Genus ?? Species ??

One female nymph, Okeanskaya in August.

This specimen is too immature for even generic determination. It is evidently a long-winged form and the ovipositor is broad and short.

\section{Family GRYLLIDAE \\ Subfamily GRYLLINAE}

\section{GRYLLUS DESERTUS Pallas}

Gryllus desertus Pallas, Reisen Prov. Russ. Reiches, vol. 1, 1771, p. 468.

One female nymph, Okeanskaya in August. 


\section{$2 \mathrm{BHL}$ Biodiversity Heritage Library}

Caudell, Andrew Nelson. 1927. "Orthopteroid insects from the Maritime Provine of Siberia." Proceedings of the United States National Museum 71(2679), 1-7. https://doi.org/10.5479/si.00963801.71-2679.1.

View This Item Online: https://www.biodiversitylibrary.org/item/32439

DOI: https://doi.org/10.5479/si.00963801.71-2679.1

Permalink: https://www.biodiversitylibrary.org/partpdf/32795

\section{Holding Institution}

Smithsonian Libraries

\section{Sponsored by}

Smithsonian

\section{Copyright \& Reuse}

Copyright Status: NOT_IN_COPYRIGHT

Rights: https://www.biodiversitylibrary.org/permissions/

This document was created from content at the Biodiversity Heritage Library, the world's largest open access digital library for biodiversity literature and archives. Visit BHL at https://www.biodiversitylibrary.org. 